\title{
Evaluasi Rekayasa Lalu Lintas Simpang Empat Bundaran Bersinyal Tugu Wisnu Surakarta
}

\author{
Meilana Evitmalasari ${ }^{1}$, Agus Sasmito ${ }^{2}$, Abdul Rokhim ${ }^{3}$ \\ Program Studi Manajemen Keselamatan Transportasi Jalan \\ Politeknik Keselamatan Transportasi Jalan \\ E-mail: evitmala@gmail.com
}

\begin{abstract}
Received 6 Oktober 2020; Reviewed 25 Oktober 2020; Accepted 10 November 2020 Journal Homepage: http://ktj.pktj.ac.id/index.php/ktj
\end{abstract}

DOI: $10.46447 / \mathrm{ktj} . v 7 \mathrm{i} 2.286$

\begin{abstract}
ABSTRAK
Salah satu upaya peningkatan keselamatan jalan ialah dengan mengurangi risiko terjadinya kecelakaan di simpang dengan cara mengoptimalkan kinerja simpang serta menurunkan jumlah konflik lalu lintas yang terjadi. Berdasarkan hal tersebut penulis melakukan penelitian upaya peningkatan keselamatan dengan cara penanganan konflik lalu lintas dan mengoptimalkan kinerja simpang. Penelitian ini bertujuan untuk memberikan penanganan simpang yang dapat diterapkan pada simpang empat Tugu Wisnu guna mewujudkan peningkatan keselamatan. Permasalahan pada simpang ini adalah terdapat ekor tundaan lalu lintas yang tertinggal pada bundaran sehingga menyebabkan konflik lalu lintas dengan arus lalu lintas pendekat simpang lainnya dengan fase APILL sama. Metode yang digunakan dalam analisis kinerja simpang menggunakan perhitungan MKJI dan disimulasikan menggunakan software Vissim 9 Full Version sedangkan metode untuk mengetahui konflik lalu lintas yang terjadi dengan menggunakan software SSAM. Kemudian memberikan usulan penanganan untuk diterapkan pada simpang empat Tugu Wisnu yaitu dengan perubahan pengaturan simpang 3 fase menjadi 4 fase dengan pergerakan lalu lintas mengelilingi bundaran serta 4 fase tanpa mengelilingi bundaran kemudian dari kedua usulan penanganan dipilih alternatif penanganan yang sesuai untuk menurunkan konflik lalu lintas dan mengoptimalkan kinerja simpang. Alternatif penanganan simpang yang dipilih berupa perubahan pengaturan simpang dengan 4 fase dengan pergerakan lalu lintas tanpa mengelilingi bundaran dapat menurunkan jumlah konflik lalu lintas sebesar $30 \%$ dan tingkat pelayanan simpang adalah $\mathrm{D}$ yang berarti terciptanya keselarasan antara keselamatan jalan dan kelancaran lalu lintas.
\end{abstract}

Kata Kunci : Keselamatan, Simpang, Konflik, Tingkat Pelayanan

\section{PENDAHULUAN}

Simpang empat Tugu Wisnu termasuk pada peringkat ketiga daerah rawan kecelakaan. Kecelakaan yang terjadi disebabkan adanya konflik lalu lintas antara kendaraan yang melakukan pergerakan di bundaran. Kendaraan memerlukan waktu lebih lama untuk melakukan gerakan memutar bundaran. Sehingga mengakibatkan konflik dengan arus dari lengan simpang lainnya. Simpang ini merupakan pertemuan antara Jl. Adi Sucipto dan Jl. Ahmad Yani dengan tipe jalan 4 lajur 2 arah terbagi. Simpang ini menggunakan pengaturan 3 fase APILL 
(Alat Pemberi Isyarat Lalu Lintas) dan terdapat bundaran. Untuk mengatasi permasalahan tersebut, maka perlu dilakukan rekayasa lalu lintas yang sesuai diterapkan pada simpang tersebut untuk mengurangi adanya konflik lalu lintas. Dengan metode rekayasa lalu lintas yang akan direkomendasikan ini diharapkan dapat mengurangi waktu pergerakan kendaraan ketika melewati bundaran sehingga dapat mengurangi konflik lalu lintas yang terjadi. Metode rekayasa lalu lintas ini sudah diterapkan pada simpang Proliman Sukoharjo.

Berdasarkan analisis data dari Satlantas Polresta Surakarta yang dilakukan oleh Tim Praktek Kerja Profesi (PKP) Kota Surakarta tahun 2019 terdapat 166 kejadian kecelakaan yang terjadi pada Jl. Adi Sucipto selama kurun waktu empat tahun (2015 - 2018). Banyaknya kejadian kecelakaan ini yang mendasari simpang ini menjadi salah satu daerah rawan kecelakaan kota Surakarta.

Tujuan penelitian adalah mengetahui kondisi eksisting pada bundaran simpang empat Tugu Wisnu, untuk menganalisis kinerja simpang pada kondisi eksisting dan rekayasa menggunakan mikrosimulasi vissim serta menerapkan hasil rekayasa lalu lintas simpang empat Tugu Wisnu menggunakan mikrosimulasi vissim.

\section{METODE}

\section{Lokasi Penelitian}

Lokasi penelitian yaitu Bundaran simpang empat bersinyal Tugu Wisnu Manahan. Bundaran Tugu Wisnu merupakan salah satu bundaran yang berlokasi di Kota Surakarta Jawa Tengah. Bundaran simpang empat Tugu Wisnu merupakan persimpangan yang menghubungkan Kabupaten Karanganyar dan Kabupaten Boyolali dengan Kota Surakarta. Bundaran ini mempertemukan empat jalan nasional yaitu Jalan Adi Sucipto (sisi barat dan timur) serta Jalan Ahmad Yani (sisi utara dan selatan). Bundaran Tugu Wisnu ini menjadi salah satu daerah rawan kecelakaan di kota Surakarta berdasarkan analisis Tim PKP (Praktek Kerja Profesi) Kota Surakarta tahun 2019. Simpang ini menggunakan pengaturan 3 fase APILL serta terdapat bundaran di tengah persimpangan. Pemilihan lokasi ini didasarkan atas pertimbangan sering terjadinya kecelakaan karena adanya konflik lalu lintas yang terjadi pada lalu lintas di bundaran. Area di sekitar bundaran terdapat kantor KODIM Surakarta, Polresta Surakarta, SPBU, serta sekolah. Hal ini mengakibatkan lalu lintas pada simpang ini sangat padat pada jam sibuk pagi atau sore.

\section{Teknik Pengumpulan Data}

Untuk mendapatkan data yang dibutuhkan dalam penelitian, peneliti perlu menentukan langkah-langkah pengumpulan data yang disebut Teknik pengumpulan data yang dibutuhkan sebagai berikut :

1. Data Primer

Pengambilan data primer dilakukan melalui pengamatan dan pencatatan langsung di lokasi penelitian. Data primer yang dibutuhkan yaitu :

a. Inventarisasi simpang

Survei inventarisasi simpang dan bundaran dilakukan hingga jarak 100 meter untuk mendapatkan data kondisi simpang yakni data geometrik simpang. Hal yang diukur adalah lebar jalan, tipe jalan, lebar bahu, jumlah 
lajur, hambatan samping, drainase, inventarisasi perlengkapan jalan dan inventarisasi bundaran.

b. Volume lalu lintas

Survei volume lalu lintas di persimpangan dilakukan dengan cara survei CTMC (Classified Turning Movement Counting) atau survei perhitungan pergerakan membelok terklasifikasi. Survei CTMC dilakukan pada tiap kaki simpang guna mendapatkan data volume lalu lintas terpadat.

c. Jumlah fase dan waktu siklus APILL

Survei waktu siklus dilakukan untuk mengetahui pengaturan waktu APILL pada masing-masing pendekat simpang. Data yang diambil dalam survei ini adalah waktu siklus dan waktu merah. Jumlah fase dan waktu siklus APILL diperoleh dari ATCS (Automatic Traffic Control System) dinas perhubungan Kota Surakarta.

d. Data kecepatan

Survei kecepatan kendaraan didapatkan dengan cara survei kecepatan sesaat (spotspeed). Survei dilakukan dengan perhitungan manual menggunakan stopwatch untuk menghitung waktu tempuh pada jarak yang telah ditentukan. Data kecepatan kendaraan selanjutnya digunakan untuk input ke dalam software Vissim.

2. Data Sekunder

Data sekunder yang dibutuhkan dalam penelitian ini adalah data kecelakaan kota Surakarta, peta jaringan jalan Kota Surakarta, jumlah penduduk Kota Surakarta dan tata guna lahan Kota Surakarta.

\section{Teknik Analisis Data}

Teknik analisis data adalah hal terpenting dalam sebuah penelitian. Karena melalui analisis data penelitian akan menghasilkan hasil penelitian yang akurat dan dapat diterima. Metode penelitian yang digunakan dalam penelitian ini menggunakan pendekatan kuantitatif. Pendekatan kuantitatif adalah suatu proses menemukan pengetahuan yang menggunakan data berupa angka sebagai alat menganalisis keterangan mengenai apa yang akan diketahui. Penelitian kuantitatif merupakan suatu penelitian yang analisisnya secara umum memakai analisis statistik.

1. Inventarisasi Jalan

Data hasil survei inventarisasi simpang selanjutnya dituangkan ke dalam bentuk visual dengan menggunakan bantuan software Autocad 2007. Melalui software tersebut diperoleh gambaran lokasi penelitian dalam bentuk dua dimensi (2D). Selain itu dapat pula disajikan dalam bentuk 3D menggunakan software Sketchup. Sedangkan untuk perlengkapan jalan dapat disajikan dalam bentuk tabel.

2. Volume Lalu Lintas

Data survei CTMC (Classified Turning Movement Counting) selanjutnya dianalisis menggunakan time series untuk mengetahui jam sibuk pada simpang bundaran Tugu Wisnu.

3. Kecepatan Kendaraan

Pengambilan sampel data kecepatan kendaraan dilakukan dengan rumus sebagai berikut: 
$n=\frac{N}{1+N(e)^{2}}$

$\mathrm{n}$ : ukuran sampel, $\mathrm{N}$ : ukuran populasi dan e : margin error dengan nilai $5 \%$ Selanjutnya data sampel digunakan untuk mendapatkan data kecepatan kendaraan yang melintas menggunakan persentil 85 .

4. Kinerja Simpang Bersinyal

a. Analisis menggunakan Manual Kapasitas Jalan Indonesia 1997

1) Kapasitas Simpang Bersinyal

Menurut Manual Kapasitas Jalan Indonesia (1997), kapasitas jalan adalah arus lalu lintas maksimum dalam satuan ekr/jam yang dapat dipertahankan sepanjang segmen jalan tertentu dalam kondisi tertentu, yaitu yang melingkupi geometrik, lingkungan, dan lalu lintas. Kapasitas jalan dihitung dengan persamaan :

$C=S x\left(\frac{g}{c}\right)$

C : Kapasitas pendekat (smp/jam), S : Arus jenuh (smp/jam hijau), g : Waktu hijau (detik) dan c : Waktu siklus

2) Arus Jenuh

Perhitungan arus jenuh dapat dinyatakan sebagai hasil perkalian dari arus jenuh dasar (So). Arus jenuh dasar adalah arus jenuh pada keadaan standar dengan faktor penyesuaian $(F)$ untuk penyimpangan dari kondisi sebenarnya dari suatu kumpulan kondisi-kondisi yang telah ditetapkan sebelumnya.

$S=$ So $x$ Fcs $x$ Fsf $x$ Fg $x$ Fp $x$ Frt $x$ Flt

$S$ : arus jenuh (smp/jam hijau), So : arus jenuh dasar, Fcs : faktor penyesuaian ukuran kota (juta penduduk), Fsf : faktor hambatan samping (kelas hambatan samping dari lingkungan jalan dan kendaraan tak bermotor), Fg : faktor penyesuaian kelandaian (\% naik atau \% turun) $\mathrm{Fp}$ : faktor penyesuaian parkir (jarak garis henti-kendaraan parkir pertama), Frt = faktor penyesuaian belok kanan (\% belok kanan), Flt = faktor penyesuaian belok kiri (\% kiri), Untuk pendekat terlindung arus jenuh dasar ditentukan sebagai fungsi dari lebar efektif pendekat (We) : $S o=600 \times W e$

3) Derajat Kejenuhan

Menurut Manual Kapasitas Jalan Indonesia (1997), derajat kejenuhan adalah rasio arus lalu lintas terhadap kapasitas untuk suatu pendekat. Derajat kejenuhan dihitung menggunakan persamaan :

$D S=\frac{Q}{C} \times \frac{(Q \times c)}{(S \times g)}$

DS : Derajat kejenuhan, Q : Arus lalu lintas (smp/jam), C : Kapasitas (smp/jam), $S$ : arus jenuh (smp/jam hijau), C : waktu siklus

4) Panjang Antrian

Panjang antrian merupakan rata-rata harian smp pada awal sinyal hijau (NQ) dihitung sebagai jumlah smp yang tersisa dari fase hijau sebelumnya (NQ1) ditambah jumlah smp yang datang selama fase merah (NQ2).

$N Q=N Q_{1}+N Q_{2}$ 
$N Q 1=0,25 \times C(D S-1)+\sqrt{(D S-1)^{2}}+\frac{8 x(D S-0,5)}{C}$

Jika DS > 0,5; selain dari hasil itu $\mathrm{NQ}_{1}=0$

$N Q_{2}=c \times \frac{1-G R}{1-G R \times D S} \times \frac{Q}{3600}$

$\mathrm{NQ}_{1}$ : Jumlah smp yang tersisa dari fase hijau sebelumnya, $\mathrm{NQ}_{2}$ : jumlah smp yang datang selama fase merah, DS : Derajat kejenuhan, C : Kapasitas (smp/jam), C : waktu siklus (detik), GR : rasio hijau Q : arus lalu lintas pada pendekat (smp/detik)

Angka henti (NS), yaitu jumlah berhenti rata-rata per kendaraan (termasuk berhenti terulang dalam antrian) sebelum melewati suatu simpang, dihitung sebagai :

$N S=0,9 \times \frac{N Q}{Q \times c} \times 3600$

C : Waktu siklus (detik) dan Q : Arus lalu lintas (smp/jam)

5) Rasio Kendaraan Terhenti

Menurut Manual Kapasitas Jalan Indonesia (1997), rasio kendaraan henti adalah rasio kendaraan yang harus berhenti akibat sinyal merah sebelum melewati simpang atau rasio dari arus lalu lintas yang terpaksa berhenti sebelum melewati garis henti akibat pengendalian sinyal. Rasio kendaraan henti dihitung dengan menggunakan persamaan :

$P s v=\min (N S, 1)$

Dimana NS adalah angka henti dan suatu pendekat

6) Tundaan

Menurut Manual Kapasitas Jalan Indonesia (1997), tundaan adalah waktu tempuh tambahan yang diperlukan kendaraan untuk melalui simpang apabila dibandingkan lintasan tanpa melalui suatu simpang. Tundaan pada suatu simpang dapat terjadi karena dua hal yaitu :

1. Tundaan Lalu lintas (DT) karena interaksi lalu-lintas dengan gerakan lainnya pada suatu simpang.

2. Tundaan Geometri (DG) karena perlambatan dan percepatan saat membelok pada suatu simpang dan/atau terhenti karena lampu merah.

Tundaan rata - rata untuk suatu pendekat $\mathrm{j}$ dihitung sebagai berikut :

$D j=D T j+D G j$

Dj : tundaan rata-rata untuk pendekat j (det/smp), DTj : tundaan lalu lintas rata-rata untuk pendekat(det/smp) dan DGj : tundaan geometri rata-rata untuk pendekat (det/smp)

Tundaan lalu lintas rata - rata pada suatu pendekat $\mathrm{j}$ dapat ditentukan dari rumus berikut ini :

$D T j=c \times A+\frac{N Q_{1} \times 3600}{C}$

DT : undaan lalu-lintas rata-rata (det/smp), C : waktu siklus yang disesuaikan (det)

$\mathrm{A}=\frac{0,5 \times(1-G R)^{2}}{(1-G R \times D S)}$

GR : rasio hijau (g/c), DS : derajat kejenuhan, $\mathrm{NQ}_{1}$ : jumlah smp yang tersisa dari fase hijau sebelumnya $\mathrm{C}$ : kapasitas (smp/jam) 
Tundaan geometri rata - rata pada suatu pendekat j dapat diperkirakan sebagai berikut:

$D G_{j}=\left(1-P_{S v}\right) \times P_{T} \times 6+\left(P_{S V} \times 4\right)$

$D_{\mathrm{j}}$ : Tundaan geometri rata-rata untuk pendekat $\mathrm{j}, \mathrm{P}_{\mathrm{sv}}$ : Rasio kendaraan terhenti pada pendekat $=$ Min $(\mathrm{NS}, 1)$, dan $\mathrm{P}_{\mathrm{T}}$ : Rasio kendaraan berbelok pada pendekat

b. Analisis menggunakan mikrsimulasi Vissim

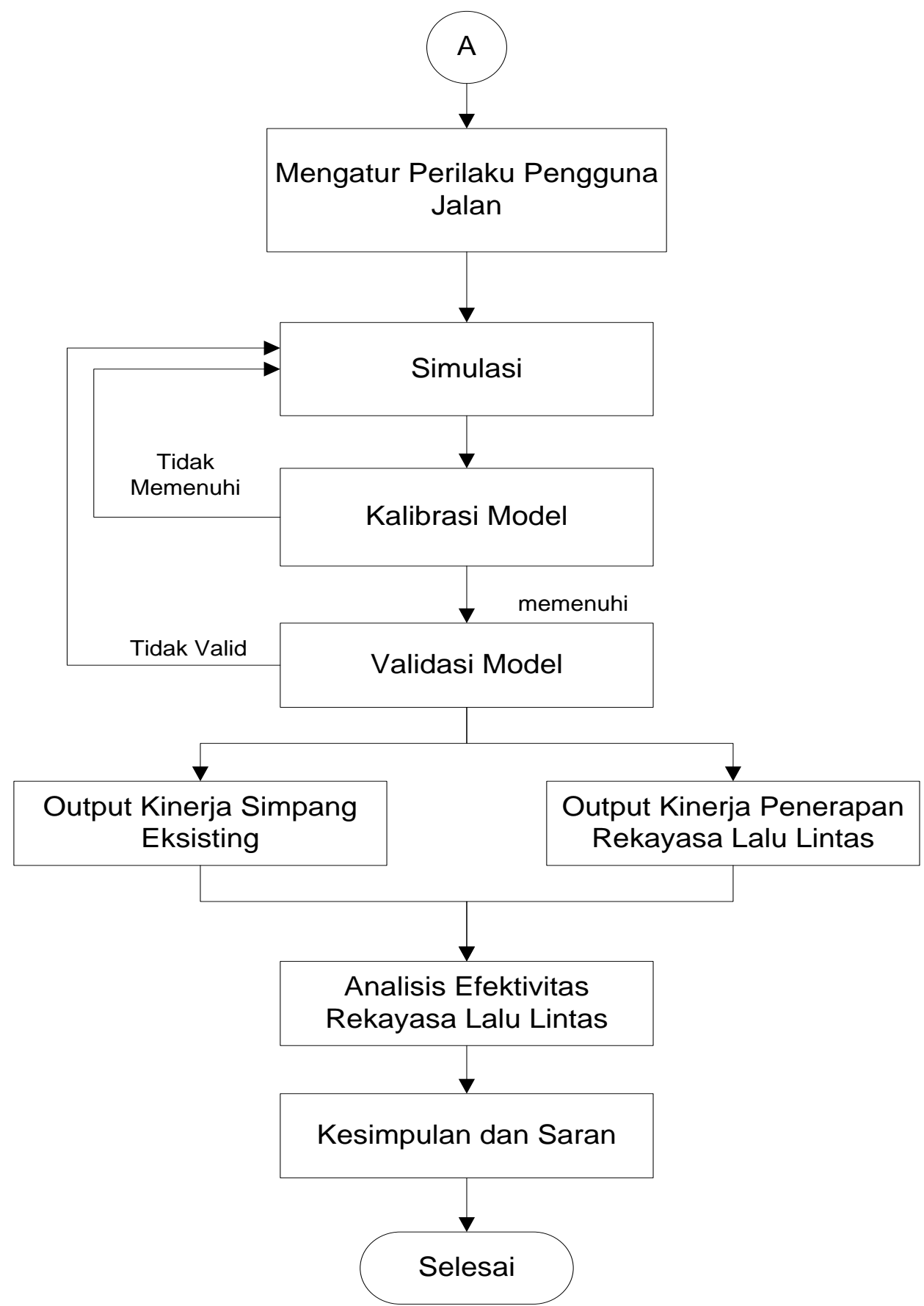

Gambar 1. Bagan Alir Vissim 


\section{HASIL DAN PEMBAHASAN}

a. Kondisi Geometrik Simpang

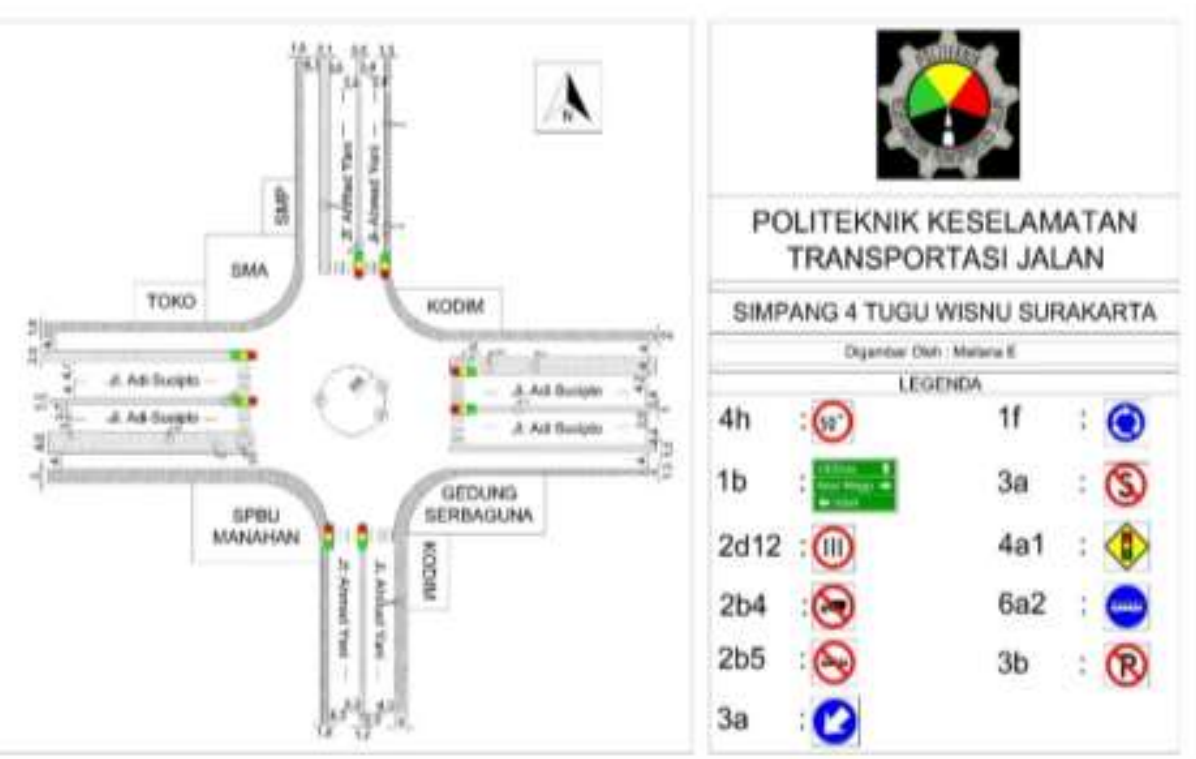

Gambar 2. Penampang Simpang Empat Tugu Wisnu

Tabel 1. Inventarisasi Simpang Empat Tugu Wisnu

\begin{tabular}{|c|c|c|c|}
\hline No & & Aspek Yang Diamati & Ukuran (meter) \\
\hline \multirow[t]{11}{*}{1.} & \multicolumn{3}{|c|}{ Kaki Simpang Jalan Adi Suipto (Timur) } \\
\hline & a. & Status Jalan & Jalan Kota \\
\hline & b. & Tipe Jalan & $4 / 2 \mathrm{D}$ \\
\hline & c. & Lebar Jalan & 15,4 meter \\
\hline & d. & $\begin{array}{l}\text { Lebar Bahu Jalan (Jalur } \\
\text { Lambat) }\end{array}$ & 4,10 meter \\
\hline & e. & Jenis Perkerasan & Aspal \\
\hline & f. & Lebar Trotoar & 3,00 meter 1,80 meter \\
\hline & g. & Marka Jalan & $\begin{array}{l}\text { Ada (marka tengah dan } \\
\text { marka tepi) }\end{array}$ \\
\hline & h. & Lampu Penerangan Jalan & Ada \\
\hline & i. & Drainase & 0,90 meter 0,80 meter \\
\hline & j. & Median Jalan & 1,3 meter \\
\hline \multirow[t]{10}{*}{2.} & \multicolumn{3}{|c|}{ Kaki Simpang Jalan Adi Sucipto (Barat) } \\
\hline & a. & Status Jalan & Jalan Nasional \\
\hline & b. & Tipe Jalan & $4 / 2 D$ \\
\hline & c. & Lebar Jalan & 15,5 meter \\
\hline & d. & $\begin{array}{l}\text { Lebar Bahu Jalan (Jalur } \\
\text { Lambat) }\end{array}$ & 4,00 meter \\
\hline & e. & Jenis Perkerasan & Aspal \\
\hline & f. & Lebar Trotoar & 1,3 meter $\quad 0,8$ meter \\
\hline & g. & Marka Jalan & $\begin{array}{l}\text { Ada (marka tengah dan } \\
\text { marka tepi) }\end{array}$ \\
\hline & h. & Lampu Penerangan Jalan & Ada \\
\hline & i. & Drainase & Ada \\
\hline
\end{tabular}




\begin{tabular}{|c|c|c|c|}
\hline No & & Aspek Yang Diamati & Ukuran (meter) \\
\hline & j. & Median Jalan & 1,00 meter \\
\hline \multirow[t]{11}{*}{3.} & \multicolumn{3}{|c|}{ Kaki Simpang Jalan Ahmad Yani (Utara) } \\
\hline & a. & Status Jalan & Jalan Nasional \\
\hline & b. & Tipe Jalan & $4 / 2 D$ \\
\hline & c. & $\begin{array}{l}\text { Lebar Jalan } \\
\text { Lebar Bahu Jalan (Jalur }\end{array}$ & 12,8 meter \\
\hline & d. & Lambat) & 4,1 meter \\
\hline & e. & Jenis Perkerasan & Aspal \\
\hline & f. & Lebar Trotoar & \multirow{2}{*}{$\begin{array}{l}\text { 1,8 meter } 1,3 \text { meter } \\
\text { Ada (marka tengah } \\
\text { marka tepi) }\end{array}$} \\
\hline & g. & Marka Jalan & \\
\hline & h. & Lampu Penerangan Jalan & Ada \\
\hline & i. & Drainase & 0,8 meter \\
\hline & j. & Median Jalan & 0,8 meter \\
\hline \multirow[t]{11}{*}{4.} & \multicolumn{3}{|c|}{ Kaki Simpang Jalan Ahmad Yani (Selatan) } \\
\hline & a. & Status Jalan & Jalan Nasional \\
\hline & b. & Tipe Jalan & $4 / 2 \mathrm{D}$ \\
\hline & c. & Lebar Jalan & 14,8 meter \\
\hline & d. & Lebar Bahu Jalan & - \\
\hline & e. & Jenis Perkerasan & Aspal \\
\hline & f. & Lebar Trotoar & \multirow{2}{*}{$\begin{array}{l}3,00 \text { meter } 1,30 \text { meter } \\
\text { Ada (marka tengah dar } \\
\text { marka tepi) }\end{array}$} \\
\hline & g. & Marka Jalan & \\
\hline & h. & Lampu Penerangan Jalan & Ada \\
\hline & i. & Drainase & 0,80 meter \\
\hline & j. & Median Jalan & 1,20 meter \\
\hline \multirow[t]{4}{*}{5.} & \multicolumn{3}{|c|}{ Bundaran } \\
\hline & a. & Diameter Bundaran & 8 meter \\
\hline & b. & Lampu Penerangan Jalan & Tidak Ada \\
\hline & c. & Rambu Lalu Lintas & Ada \\
\hline
\end{tabular}

Sumber : Hasil Analisis, 2020

b. Volume Lalu Lintas

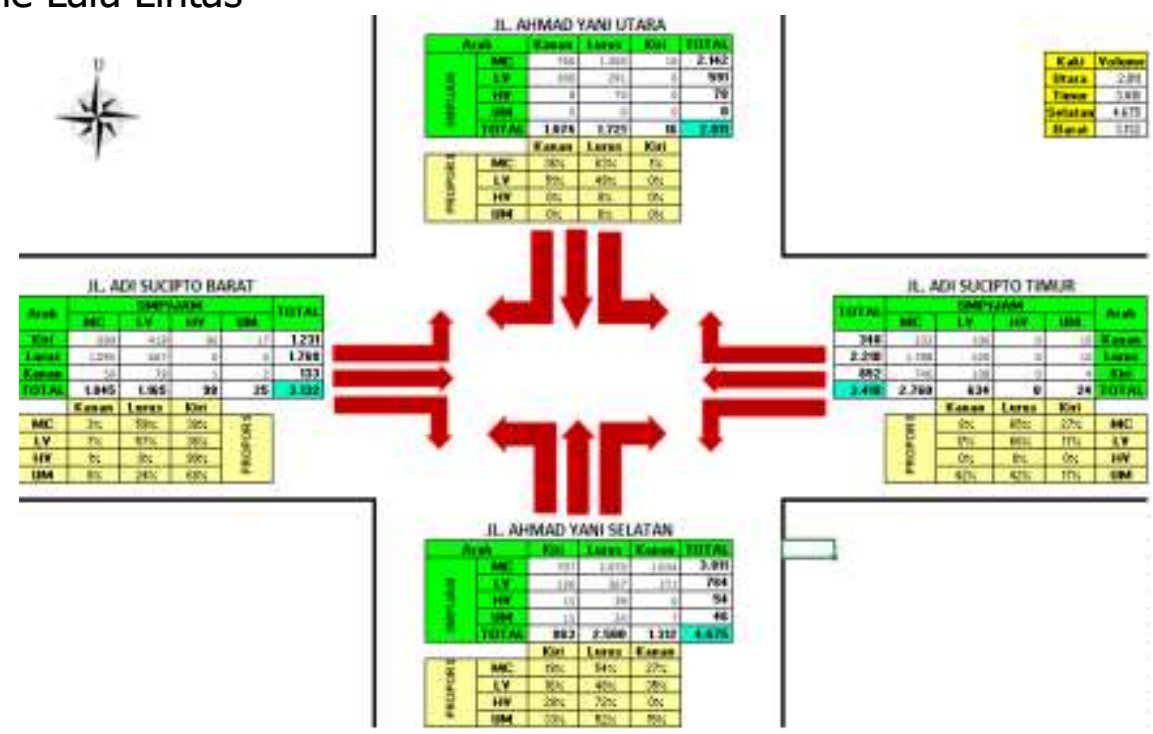

Gambar 3. Matrik Volume Lalu Lintas 
Pengamatan arus lalu lintas pada Simpang Tugu Wisnu dilakukan selama enam jam, dimana pengamatan tersebut dilakukan pada waktu sibuk. Pengamatan yang dilakukan menggunakan metode CTMC (Classified Turning Moving Counting) dimana dalam proses pengamatan arus lalu lintas pada simpang empat tugu wisnu dilakukan berdasarkan arah pergerakan kendaraan, seperti belok kanan, belok kiri dan lurus. Volume lalu lintas pada simpang empat Tugu Wisnu terbanyak pada peak hours pagi yakni pada pukul $06.30-07.30$ WIB. Volume lalu lintas terpadat pada lengan barat atau Jalan Adi Sucpto Barat dengan total $3132 \mathrm{smp} / \mathrm{jam}$.

c. Kecepatan Kendaraan

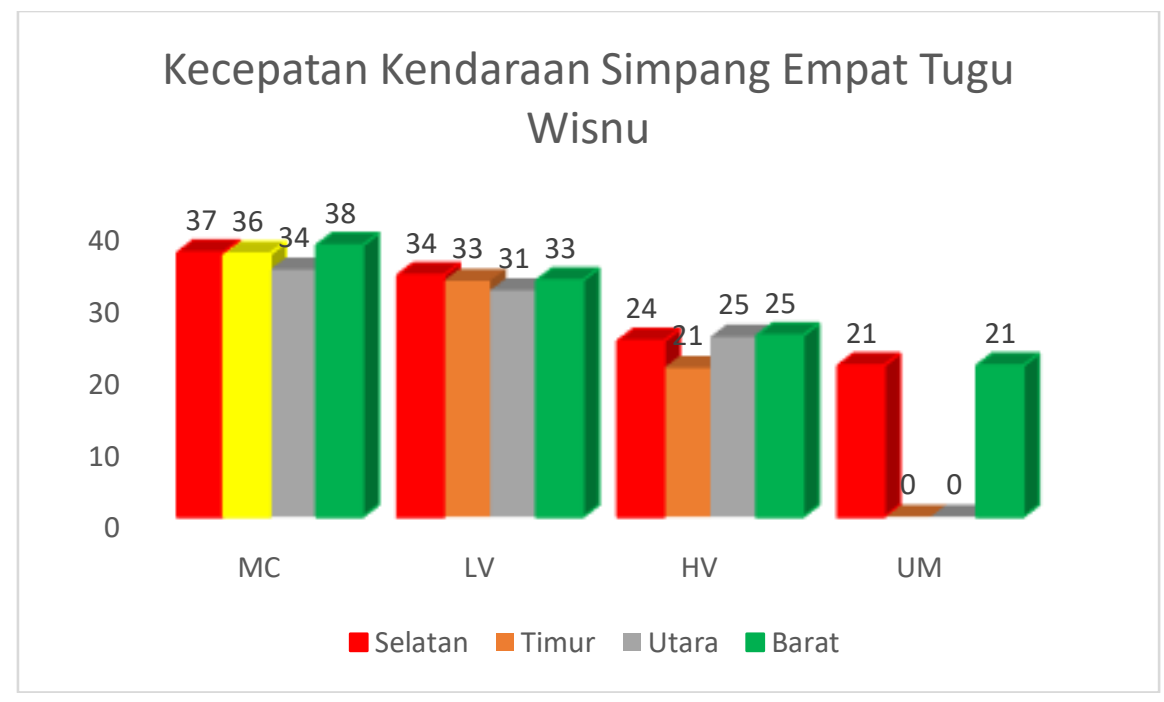

Gambar 4. Grafik Kecepatan

Kecepatan kendaraan diambil dari hasil observasi lapangan berdasarkan jenis kendaraan yang terdapat di lapangan. Berdasarkan hasil survei lapangan, jenis kendaraan dikelompokkan menjadi sepeda motor, kendaraan ringan, kendaraan berat serta kendaraan tidak bermotor. Untuk mengetahui kecepatan kendaraan yang melintas pada simpang empat bersinyal Tugu Wisnu dilakukan survei spot speed dengan mengambil sampel pada tiap jenis kendaraan yaitu pada sepeda motor, kendaraan ringan dan kendaraan berat. Pengukuran kecepatan dilakukan secara manual dengan menggunakan stopwatch untuk menghitung waktu tempuh dan menggunakan 2 patok dengan jarak 20 meter. Karena banyaknya kendaraan yang melintas maka pengukuran dilakukan dengan mengambil sampel.

d. Waktu Siklus APILL

Tabel 2. Waktu Siklus Kondisi Eksisting

\begin{tabular}{l|lllllllll}
\hline 3 Fase & \multicolumn{7}{c}{111} & & \\
\hline utara & 28 & 3 & 4 & 31 & & 4 & 37 & 4 \\
selatan & 31 & & 4 & 28 & 3 & 4 & 37 & 4 \\
barat dan timur & 31 & & 4 & 31 & & 4 & 34 & 3 & 4 \\
\hline
\end{tabular}

Sumber : Hasil Analisis, 2020

Meilana Evitmalasari, Agus Sasmito, Abdul Rokhim 
e. Kinerja Simpang

1) Hasil Analisis menggunakan Manual Kapasitas Jalan Indonesia 1997 Berdasarkan perhitungan yang telah disesuaikan dengan kondisi eksisting pada simpang empat bersinyal Tugu Wisnu diperoleh data kinerja simpang sebagai berikut :

Tabel 3. Hasil Perhitungan Kinerja Simpang menggunakan MKJI 1997

\begin{tabular}{lcccccc}
\hline & $\begin{array}{c}\text { Kapasitas } \\
\text { (smp/jam) }\end{array}$ & $\begin{array}{c}\text { Arus } \\
\text { Jenuh }\end{array}$ & $\begin{array}{c}\text { Derajat } \\
\text { Kejenuhan }\end{array}$ & $\begin{array}{c}\text { Panjang } \\
\text { Antrian }\end{array}$ & $\begin{array}{c}\text { Angka } \\
\text { Henti }\end{array}$ & Tundaan \\
\hline $\begin{array}{l}\text { Jalan Ahmad } \\
\begin{array}{l}\text { Yani (Utara) } \\
\text { Jalan Ahmad } \\
\text { Yani }\end{array}\end{array}$ & 2065 & 8185 & 0,54 & 42,91 & 0,78 & 40,55 \\
$\begin{array}{l}\text { Selatan) } \\
\text { Jalan Adi } \\
\begin{array}{l}\text { Sucipto } \\
\text { (Timur) }\end{array}\end{array}$ & 1815 & 7197 & 0,88 & 76,35 & 0,91 & 48,69 \\
$\begin{array}{l}\text { Jalan Adi } \\
\text { Sucipto } \\
\text { (Barat) }\end{array}$ & 1949 & 6362 & 0,89 & 211,35 & 0,90 & 45,64 \\
\hline Sumber: & 2436 & 7952 & 1,28 & 169,08 & 1,19 & 73,65 \\
\hline
\end{tabular}

Sumber : Hasil Analisis, 2020

2) Hasil Analisis menggunakan mikrosimulasi Vissim

Selain analisis kinerja simpang menggunakan MKJI 1997, analisis juga dilakukan menggunakan software Vissim. Melalui mikrosimulasi menggunakan software vissim dengan pergerakan lalu lintas yang hamper mirip dengan kondisi sebenarnya diketahui kinerja simpang empat Tugu Wisnu sebagai berikut :

Tabel 4. Hasil Analisis Menggunakan Mikrosimulasi Vissim

\begin{tabular}{lcccc}
\hline & & Panjang Antrian & Tundaan & Tingkat Pelayanan \\
\hline $\begin{array}{l}\text { Jl. Ahmad } \\
\text { (utara) }\end{array}$ & Yani & 28,15 & 28,28 & $\mathrm{D}$ \\
$\begin{array}{l}\text { Jl. Ahmad } \\
\text { (selatan) }\end{array}$ & Yani & 18,55 & 24,56 & $\mathrm{C}$ \\
$\begin{array}{l}\text { Jl. Adi Sucipto (timur) } \\
\text { Jl. Adi Sucipto (barat) }\end{array}$ & 13,9 & 23,25 & $\mathrm{C}$ \\
\end{tabular}

Sumber : Hasil Analisis, 2020

f. Konflik Lalu Lintas Kondisi Eksisting

Analisis konflik lalu lintas dengan menggunakan Software SSAM

Tabel 5. Konflik Lalu Lintas

\begin{tabular}{ccc}
\hline \multicolumn{3}{c}{ Jenis Konflik } \\
\hline Crossing & Rear End & Lane Change \\
25 & 164 & 44 \\
\hline
\end{tabular}

Sumber : Hasil Analisis, 2020

Meilana Evitmalasari, Agus Sasmito, Abdul Rokhim 
Pada kondisi eksisting simpang bersinyal Tugu Wisnu menerapkan pengaturan lalu lintas menggunakan tiga fase APILL, dalam hal ini diketahui bahwa Level of Service simpang pada kondisi eksisting adalah E. Serta terdapat konflik lalu lintas yang terjadi. Untuk mengoptimalkan kinerja simpang serta mengurangi jumlah konflik lalu lintas maka diperlukan beberapa alternatif penanganan simpang.

Usulan penanganan yang hendak dilakukan :

1. Pengaturan Cycle Time dan Empat Fase APILL dengan Pergerakan Mengelilingi Bundaran Pada Usulan Penanganan

a. Merubah waktu siklus APILL

Tabel 6. Waktu Siklus APILL Usulan Penanganan 1

\begin{tabular}{|c|c|c|c|c|c|c|c|c|c|c|c|}
\hline 4 fase & \multicolumn{10}{|c|}{214} \\
\hline utara & 32 & 2 & 3 & \multicolumn{2}{|c|}{54} & 3 & 46 & 3 & 69 & 3 \\
\hline selatan & 34 & 3 & 52 & 2 & 3 & 46 & 3 & 69 & 3 \\
\hline timur & 34 & 3 & 54 & 3 & 44 & 2 & 3 & 69 & 3 \\
\hline barat & 34 & 3 & 54 & 3 & 46 & 3 & 67 & 2 & 3 \\
\hline
\end{tabular}

Sumber : Hasil Analisis, 2020

b. Kinerja Simpang

Tabel 7. Hasil Analisis Kinerja Simpang Usulan Penanganan 1

\begin{tabular}{lccc}
\hline \multicolumn{1}{c}{ Kaki Simpang } & $\begin{array}{c}\text { Panjang } \\
\text { Antrian }\end{array}$ & Tundaan & LOS \\
\hline Jl. Ahmad Yani (utara) & 64,53 & 49,50 & $\mathrm{E}$ \\
Jl. Ahmad Yani (selatan) & 31,06 & 42,15 & $\mathrm{E}$ \\
Jl. Adi Sucipto (timur) & 22,87 & 37,87 & $\mathrm{D}$ \\
Jl. Adi Sucipto (barat) & 61,30 & 51,88 & $\mathrm{E}$ \\
\hline
\end{tabular}

Sumber : Hasil Analisis, 2020

c. Konflik Lalu Lintas

Tabel 8. Jumlah Konflik Lalu Lintas Usulan Penanganan 1

Jenis Konflik

\begin{tabular}{ccc}
\hline Crossing & Rear End & Lane Change \\
0 & 155 & 13 \\
\hline
\end{tabular}

Sumber : Hasil Analisis, 2020

Pada simulasi usulan penanganan menggunakan mikrosimulasi vissim sudah tidak terdapat konflik crossing, hal ini terjadi karena pengaturan fase simpang serta waktu siklus simpang sudah dirubah menjadi empat fase dengan total waktu siklus 214 detik. Konflik lalu lintas mengalami penurunan pada usulan penanganan empat fase APILL dengan mengelilingi bundaran.

2. Pengaturan Cycle Time Empat Fase APILL dengan Pergerakan Tanpa Memutar Bundaran. Waktu siklus APILL tetap sama dengan usulan penanganan yang pertama yakni 214 detik namun pergerakan lalu lintas tanpa mengelilingi bundaran. 
a. Kinerja Simpang

Tabel 9. Hasil Analisis Kinerja Simpang Usulan Penanganan 2

\begin{tabular}{lccc}
\hline \multicolumn{1}{c}{ Kaki Simpang } & $\begin{array}{c}\text { Panjang } \\
\text { Antrian }\end{array}$ & Tundaan & LOS \\
\hline Jl. Ahmad Yani (utara) & 30,08 & 40,15 & $\mathrm{E}$ \\
Jl. Ahmad Yani (selatan) & 23,70 & 30,06 & $\mathrm{D}$ \\
Jl. Adi Sucipto (timur) & 11,48 & 35,60 & $\mathrm{D}$ \\
Jl. Adi Sucipto (barat) & 29,95 & 42,65 & $\mathrm{E}$ \\
\hline
\end{tabular}

Sumber : Hasil Analisis, 2020

b. Konflik Lalu Lintas

Tabel 10. Jumlah Konflik Lalu Lintas Usulan Penanganan 2

Jenis Konflik

\begin{tabular}{ccc}
\hline Crossing & Rear End & Lane Change \\
0 & 82 & 4 \\
\hline
\end{tabular}

Sumber : Hasil Analisis, 2020

Berdasarkan hasil analisi diatas dengan menerapkan usulan penanganan kedua yakni empat fase APILL tanpa mengelilingi bundaran tidak terdapat konflik crossing, konflik rear end dan lane change antara kendaraan satu dengan lainnya menurun daripada usulan penanganan empat fase dengan mengelilingi bundaran.

Tabel 11. Kondisi Eksisting dan Rekomendasi

\begin{tabular}{|c|c|c|c|}
\hline Pembeda & Kondisi Eksisting & $\begin{array}{c}\text { Usulan Penanganan } \\
1\end{array}$ & $\begin{array}{c}\text { Usulan Penanganan } \\
2\end{array}$ \\
\hline Tundaa & $m$ & 45,35 smp/jam & $37,11 \mathrm{smp} / \mathrm{jam}$ \\
\hline g Antrian & 23 & 2 & 2 \\
\hline LOS & D & $\mathrm{E}$ & D \\
\hline Waktu Siklus & 111 detik & 14 d & 214 detik \\
\hline $\begin{array}{l}\text { Pengaturan fase } \\
\text { APILL }\end{array}$ & 3 fase & 4 fase & $4 \mathrm{f}$ \\
\hline $\begin{array}{l}\text { Pergerakan Lalu } \\
\text { Lintas }\end{array}$ & $\begin{array}{l}\text { Mengelilingi } \\
\text { Bundaran }\end{array}$ & Mengelilingi Bundaran & $\begin{array}{l}\text { Tanpa mengelilingi } \\
\text { bundaran }\end{array}$ \\
\hline Jumlah Konflik & $\begin{array}{l}\text { Crossing : } 25 \\
\text { Rear end : } 164 \\
\text { Lane Change : } 44\end{array}$ & $\begin{array}{l}\text { Crossing : } 0 \\
\text { Rear end : } 155 \\
\text { Lane Change : } 13\end{array}$ & $\begin{array}{l}\text { Crossing : } 0 \\
\text { Rear end : } 82 \\
\text { Lane Change : } 4\end{array}$ \\
\hline
\end{tabular}

Sumber : Hasil Analisis, 2020

\section{SIMPULAN}

Inventarisasi kondisi eksistng simpang empat bersinyal Tugu Wisnu, pada pendekat kaki simpang memiliki tipe jalan empat lajur terbagi dua arah dan diperkeras dengan flexible pavement. Terdapat jalur lambat pada ruas jalan Adi Sucipto barat dan timur serta Jalan Ahmad Yani (utara). Sudah terdapat fasilitas pejalan kaki berupa trotoar dan zebracross pada setiap kaki simpang. Pada tiap kaki simpang menggunakan APILL untuk mengatur arus lalu lintas. Perlengkapan jalan yang terpasang sudah memadai diantaranya rambu lalu lintas, marka, dan PJU. Tingkat pelayanan simpang kondisi eksisting D dengan 25 konflik crossing, 
164 rear end serta 44 lane change. Usulan penanganan yang efektif adalah dengan penerapan 4 fase APILL dengan pergerakan lalu lintas tanpa mengelilingi bundaran. Diketahui tingkat pelayanan simpang $D$ dengan nilai tundaan 37,12 detik, tidak terdapat konflik crossing, terdapat 82 rear end dan 4 lane change. Usulan penanganan tambahan menggunakan metode 3E's yaitu Engineering, Education, Enforcement untuk mengoptimalkan kinerja simpang dan mengurangi konflik lalu lintas.

\section{SARAN}

Untuk menyeimbangkan antara kelancaran dan keselamatan di perlukan penanganan secara bersamaan antara tiga aspek yakni engineering, enforcement, serta education. Penelitian selanjutnya perlu dilakukan survei yang lebih makro.

\section{DAFTAR PUSTAKA}

Undang - Undang Nomor 22 tahun 2009 tentang Lalu Lintas Dan Angkutan Jalan. Jakarta

Peraturan Menteri Perhubungan Nomor 96 Tahun 2015 tentang Pedoman Pelaksanaan Kegiatan Manajemen dan Rekayasa Lalu Lintas. Jakarta

Peraturan Menteri Perhubungan Nomor 34 Tahun 2014 tentang Marka Jalan. Jakarta

Peraturan Menteri Perhubungan Nomor 13 Tahun 2014 tentang Rambu Lalu Lintas. Jakarta

Peraturan Menteri Perhubungan Nomor 62 Tahun 1993 tentang Alat Pemberi Isyarat Lalu Lintas

Badan Pusat Statistik. 2019. Surakarta Dalam Angka. Surakarta : Badan Pusat Statistik

Direktorat Jenderal Bina Marga. 1997. Manual Kapasitas Jalan Indonesia. Jakarta: Direktorat Jenderal Bina Marga, Departemen Pekerjaan Umum

Efterpi, Fotini. 2017. Quality of Serrvice (QOS) of Urban Roundabouts : a literature review. Yunani. International Journal of Transportation Systems. Vol. 2.

Khisty, C. Jotin, dan B. Kent Lall. 2003. Dasar-Dasar Rekayasa Transportasi. Jakarta: Erlangga

Mayuni, Siti, 2015. Analisis Kinerja Bundaran Bersinyal (Studi Kasus Bundaran Bersinyal Digulis, Kota Pontianak)

Morlok, Edward K. 1988. Pengantar Teknik Dan Perencanaan Transportasi. Jakarta: Erlangga

Muhammad Zulfikar. 2017. Penilaian Kinerja Simpang Bundaran Tugu Bancar Kabupaten Purbalingga Dengan Metode MKJI dan Gaop Acceptance. Tegal : Politeknik Keselamatan Transportasi Jalan.

Rosehan, Anwar. 2012, Analisis Bundaran Pada Simpang Empat Jalan A. Yani KM 36 Di Banjarbaru. Indonesia. Jurnal Teknik Unlam Banjarmasin. Vol. 15, No.1.

Ulfah, Marissa. 2017. Mikrosimulasi Lalu Lintas Pada Simpang Tiga Dengan Software Vissim (Skripsi). Makassar: Universitas Hasanuddin.

American Highway Capacity Manual. 2010. Amerika. Highway Capacity Manual 